and in a case of plasmacytic reticulium cell sarcoma (Okano, Azar \& Osserman, 1966).

The course of the disease seems to be progressive inspite of temporary response, reported in a few cases, to cytotoxic drugs and systemic coticosteroids. In our case, the course of the disease took about 18 months from the time she developed symptoms until she died.

In conclusion, the differential diagnosis of alpha chain disease from other malignant lymphomas that may involve the small intestine and other proliferative syndromes with dysproteinaemia appears to depend on the identification of heavy alpha chain polypeptide $(\operatorname{IgA})$ in the serum and urine together with other clinical and pathological characteristics.

\section{Acknowledgment}

We would like to thank Professor J. C. Rambaud, Professor M. Seligmann and Dr A. Galian of Paris for conducting serum electrophoresis, checking up the histological materials and for their constructive correspondence. Our thanks are also due to Dr Adnan Rayis for referring the patient.

\section{References}

Besis, M.C., Breton-Gorius, J. \& Binet, J.L. (1963) Etude comparée du plasmocytomie et du syndrome de Waldenstrom. Nouvelle revue française d'hématologie, 3, 159.
Dutcher, T.F. \& FAHEY, J.L. (1959) The histopathology of the macroglubulinemia of Waldenstrom. Journal of the National Cancer Institute, 22, 887.

Eidelman, S., Parkins, J.J. \& Rubin, C.E. (1966) Abdominal lymphoma presenting as malabsorption. A clinicopathological study of nine cases in Israel and review of the literature. Medicine, 45, 111.

Franklin, E.C., Lowenstein, J., Bigelow, B. \& Meltzer, M. (1964) Heavy chain disease, a new disorder of serum Y-globulins. Report of the first case. American Journal of Medicine, 37, 332.

Okano, H., Azar, H.A. \& Osserman, E.F. (1966) Plasmacytic reticulum cell sarcoma, case report with electron microscopic studies. American Journal of Clinical Pathology, 46, 546.

Rambaud, J.C., Bognel, C., Prost, A., Bernier, J.J., Le Quintrec, Y., Lambling, A., Danon, F., Hurez, D. \& SeligmanN, M. (1968) Clinico pathological study of a patient with mediterranean type of abdominal lymphoma and a new type of IgA abnormality 'alpha chain disease'. Digestion, 1, 321.

Rambaud, J.C., Matuchansky, C., Bognel, J.C., Bognel, C., Bernier, J.J., Scotto, J., Perol, C., Ferrier, J.P., Milaesco, E., Hurez, D. \& SeligmanN, M. (1970) Nouveau cas de maladie des chaines alpha chez un Eurasien. Annales médicine interne, 121, 135.

Seligmann, M., Mehaesco, E., Hurez, D., Mehaesco, C., Preud'homme, J.L. \& Rambaud, J.C. (1969) Immunochemical studies in four cases of alpha chain disease. Journal of Clinical Investigations, 48, 2374.

Seligmann, M. \& Rambaud, J.C. (1969) IgA abnormalities in abdominal lymphoma ( $\alpha$-chain disease). Israel Journal of Medical Sciences, 5, 151.

WALDENSTROM, J. (1958) Die Macroglobulinaemia Ergebn-in. Med. U. Kinderh, 9, 586.

\title{
Precocious sexual development in an untreated cretin
}

\author{
D. T. D. BulugahapitiYa \\ M.B., B.S.(Cey.), M.R.C.P., M.R.C.P.(Glas.), D.C.H. \\ Government Hospital Gampaha, Ceylon
}

\begin{abstract}
UNTREATED hypothyroidism usually results in retardation of physical and mental development. Sexual development too is retarded and corresponds approximately to the bone age. Rarely, however, thyroid deficiency in childhood may be associated with precocious sexual development. Bergstrand (1955) and Silver (1958) described girls with juvenile hypothyroidism who had precocious menstruation and other signs of sexual development. Van Wyk \& Grumbach (1960) reported three girls with juvenile hypothyroidism, breast enlargement, galactorrhoea and early menstruation. Kendle (1905) described an untreated cretin with precocious puberty.
\end{abstract}

The case reported here is a 10 -year-old untreated cretin with precocious sexual development.

\section{Case report}

A.R.C. (date of birth: 7.10.60) was admitted to hospital on 4 February 1971 with a history of lower abdominal pain and vaginal bleeding of 6 days' duration. There was no history of headache, fever or vomiting.

Vaginal bleeding had also occurred at 5 years and $7 \frac{1}{2}$ years of age lasting 4 days and 6 days respectively. The patient is the last in a family of six. Her parents are first cousins. An elder sister of the patient has a 
mild enlargement of the thyroid but no evidence of thyroid disease. There is no family history of precocious puberty. The mother's menarche had occurred at 12 years and an elder sister's at 14 years.

The patient was born at full term after an uneventful pregnancy. From infancy she had been observed to be inactive and constipated. Physical and mental development had been slow. The child had spoken single words at 2 years and walked at 3 years. The first tooth had appeared at 4 years of age. She had not attended school.

On examination the patient showed signs of severe thyroid deficiency. Weight $32 \mathrm{lb}$, height 34 in. The head circumference was $18 \mathrm{in}$. and the chest circumference 21 in.; heel-to-pubis 14 in. She was inactive and showed little interest in the surroundings. The mucous membranes were pale. The skin was coarse and dry with scars of infected scabies. The breasts were enlarged and the nipples protruded slightly (Fig. 1). The areolae were not pigmented. Axillary and pubic hair were not present. The thyroid gland was not palpable. Pulse $72 / \mathrm{min}$, BP $100 / 70$. The heart was slightly enlarged. The abdomen was protuberant and the liver was palpable at the costal margin. The nervous system did not show any

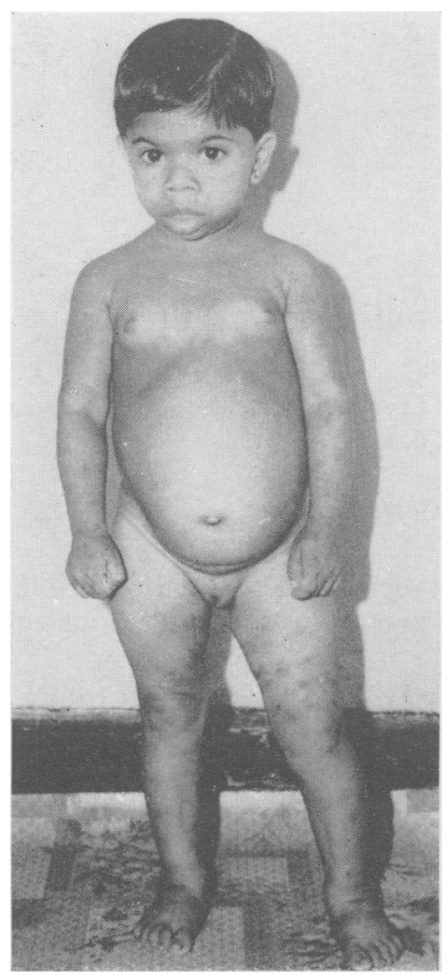

FIG. 1. The patient. abnormality except for the delayed relaxation phase of the deep reflexes. There was no papilloedema. The labia majora showed slight brownish pigmentation. The clitoris was not enlarged. The labia minora were hypertrophied. The hymen was intact. Moderate vaginal bleeding was observed. Rectal examination revealed an anteverted uterus about 2 in. long and 1 in. wide. The ovaries and adnexae could not be palpated.

Investigations. $\mathrm{Hb}$ was $4.4 \mathrm{~g} / 100 \mathrm{ml}$. The blood film showed anisocytosis, poikilocytosis, hypochromia and a few target cells. WBC $9600 / \mathrm{mm}^{3}$; neutrophils, $64 \%$; lymphocytes, $30 \%$ and eosinophils $6 \%$. Urinalysis showed a trace of albumin, SG 1020. Serum cholesterol $450 \mathrm{mg} / 100 \mathrm{ml}$, and alkaline phosphatase $10 \mathrm{KA}$ units. The 24-hr excretion of 17 ketosteroids was $1 \cdot 1 \mathrm{mg}$ and 17 ketogenic steroids $3.9 \mathrm{mg}$. The 24-hr ${ }^{131}$ I uptake by the thyroid was $7 \cdot 2 \%$ of the administered dose. Examination of the vaginal discharge showed remnants of endometrial tissue.

Radiological examination (Fig. 2). The bone age was $1 \frac{1}{2}$ years. The lower femoral epiphysis showed dysgenesis. The sella turcica was within normal limits for the chronological age. The cardiac shadow was enlarged.

Subsequent course. The patient was given iron dextran injections because of the iron deficiency anaemia. Thyroid replacements were not given at this stage. The vaginal bleeding stopped 4 days after admission. The girl was then kept under observation. Fifteen days after admission vaginal bleeding recurred. This time the blood loss was small and lasted only 2 days. Cytological examination of a scraping from the vaginal mucosa 7 days after this episode showed basal cells 0 , intermediate cells $99 \%$ and cornified cells $1 \%$. Two months later the patient

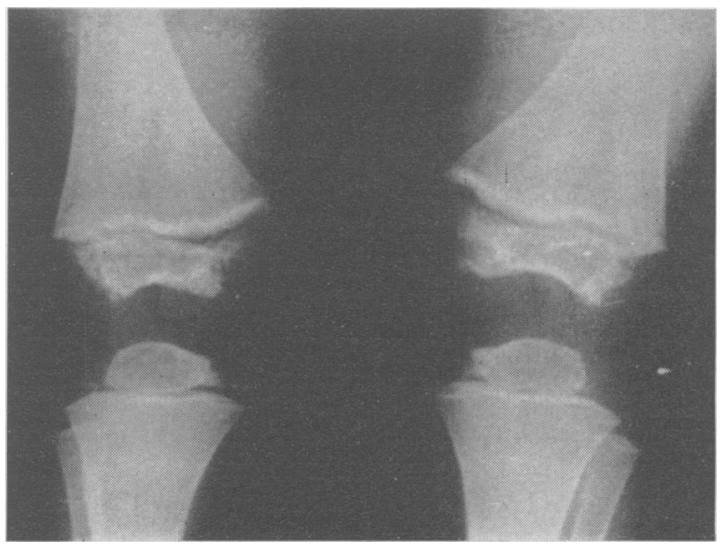

FIG. 2. Lower femoral epiphysis showing dysgenesis. 
had another episode of vaginal bleeding. The blood loss was moderate and lasted 6 days. One week later cytological examination of a vaginal scraping was repeated and showed $100 \%$ intermediate cells.

At this stage the patient was started on $0.05 \mathrm{mg}$ thyroxine daily. She has been followed up for 3 months and has had no further vaginal bleeding. She has lost $5 \mathrm{lb}$ in weight and gained 1 in. in height. Now she is more active and plays with other children. The breast enlargement has disappeared and the labia minora are less prominent. She is no longer constipated.

\section{Discussion}

This patient has been hypothyroid from birth as shown by the presence of dysgenesis in the lower femoral epiphysis. Other signs of thyroid deficiency too have been present from infancy. The very low 24-hr ${ }^{131}$ I uptake by the thyroid and a bone age of only $1 \frac{1}{2}$ years at 10 years of age show that the thyroid deficiency has been of a severe degree.

The parents of this girl are first cousins. Consanguinity has been observed in a high proportion of endemic goitrous cretins. The girl however did not have a goitre. Non development of adequate thyroid tissue is the likely cause of hypothyroidism in this patient. Absence of a rise in ${ }^{131}$ I uptake after TSH stimulation would have confirmed primary deficiency of the thyroid gland but this test could not be done.

In this patient the first episode of vaginal bleeding had occurred at 5 years of age and it did not recur for $2 \frac{1}{2}$ years. More recently, bleeding occurred at shorter intervals. The absence of menstruation for $2 \frac{1}{2}$ years after the first episode of vaginal bleeding compares with the long period of amenorrhoea which sometimes follows normal menarche. In the cretin with precocious puberty described by Kendle (1905) menstruation had started at 5 years of age and at 9 years she had coarse axillary and pubic hair in addition to other signs of puberty. In the patient described here as in those reported by Bergstrand (1955), Silver (1958) and Van Wyk \& Grumbach (1960), axillary and pubic hair were absent. Unlike the patients described by Van Wyk \& Grumbach (1960) the vaginal mucosa described here showed only $1 \%$ cornified cells, on one occasion only. It could be that severe thyroid deficiency had arrested the maturation of the vaginal mucosal cells. In this patient as in those reported by other authors the pubertal changes regressed and vaginal bleeding did not recur after the institution of thyroxine therapy.

The precocious sexual development in hypothyroid patients could result from a derangement of pituitary function. A pituitary tumour resulting in impaired TSH and excessive gonadotrophin production could explain the symptoms in this girl. However, the presence of thyroid deficiency from birth and the absence of any signs of raised intracranial pressure or visual defect make this unlikely.

Van Wyk \& Grumbach (1960) postulate a derangement of the pituitary feed-back mechanism to explain the association of precocious puberty with hypothyroidism. Failure in development or destruction of an endocrine gland normally results in an increased production of the corresponding trophic hormone by the pituitary which may give rise to hyperplasia of the trophic-hormone-producing cells and enlargement of the pituitary. For example, enlargement of the pituitary has been observed in longstanding myxoedema (Russfield, 1956). Animal experiments have demonstrated that the pituitary may respond to the failure of a target organ by excessive production of not only the corresponding trophic hormone but other trophic hormones as well. Clinical observations such as the increased incidence of thyroid and adrenal adenomas in patients with Klinefelter's syndrome (Burt et al., 1954) likewise show that the pituitary feed-back mechanism is not very specific. A similar overlap in the pituitary feedback mechanism and over-production of gonadotrophins in addition to TSH could explain the association of precocious puberty with hypothyroidism. Thyroxine therapy should then supress the over production of TSH and with it the excessive output of gonadotrophins. In the patient described here as in those reported by other authors thyroxine therapy resulted in cessation of menstruation and regression of other signs of puberty along with the improvement in the signs of hypothyroidism so that pituitary dysfunction in these patients is reversible.

Van Wyk \& Grumbach (1960) have discussed the possible site of the hormonal overlap. Since the pituitary feed-back is in part mediated through the hypothalamic nuclei, they postulate that the overlap might occur at this level due to lack of specificity in the hypothalamic mechanisms. The overlap might also be at a cellular level in the pituitary resulting from the hyperplasia of more than one type of cell.

The girl described in this report had had no thyroid replacement therapy for 10 years and the bone age and other parameters of development were markedly retarded. Therefore, even with adequate thyroxine replacement she will not attain satisfactory physical and mental development and true puterty is likely to be delayed.

\section{Acknowledgments}

I would like to thank the Director of Health Services, Ceylon, for permission to publish this case.

\section{References}

Bergstrand, C.G. (1955) A case of hypothyroidism with signs of precocius sexual development. Acta Endocrinologica, 20, 338 . 
Burt, A.S. Reiner, L., Cohen, R.B. \& SNiffen, R.C. (1954) Klinefelter's syndrome: Report of autopsy with particular reference to histology and histochemistry of the endocrine glands. Journal of Clinical Endocrinology, 14, 719.

KENDLE, F.W. (1905) A case of precocious puberty in a female cretin. British Medical Journal, 1, 246.

Russfield, A.B. (1956) Histology of the human hypophysis in thyroid disease-hypothyroidism, hyperthyroidism and cancer. Journal of Clinical Endocrinology, 15, 1393.
SILVER, H.K. (1958) Juvenile hypothyroidism with precocious sexual development. Journal of Clinical Endocrinology, 18, 886.

Van WyK, J.J. \& Grumbach, M.M. (1960) Syndrome of precocious menstruation and galactorrhoea in juvenile hypothyroidism; An example of hormonal overlap in pituitary feed back. Journal of Pediatrics, 57, 416. 